\title{
Monitoring water stress and arboreal forests situation under different irrigation systems using satellite images
}

\author{
Amr. K. Mahmoud ${ }^{1}$, A.M. El-Gindy², A.H. Mohamed ${ }^{3 *}$ \\ ${ }^{1}$ Department of Chemical and Soil physics -Desert Research Center (DRC), Cairo, Egypt \\ ${ }^{2}$ Department. of Agric. Eng., Fac. of Agric., Ain Shams Univ., Shoubra El-kheima, Cairo, Egypt \\ ${ }^{3}$ Department of Plant Ecology and Rangeland Management, Desert Research Center (DRC), Cairo, Egypt. \\ *Corresponding author (akherashy@yahoo.com)
}

Received: 14 Dec 2021; Received in revised form: 07 Feb 2022; Accepted: 15 Feb 2022; Available online: 22 Feb 2022

(C2022 The Author(s). Published by Infogain Publication. This is an open access article under the CC BY license

(https://creativecommons.org/licenses/by/4.0/).

\begin{abstract}
Egypt offers a great opportunity for large-scale afforestation due to availability of sufficient desert lands and huge volume of sewage water. Several forest plantations were established that irrigated with treated waste water using different irrigation systems. Improper management and failure of irrigation system led to water stress and negative impact of wood trees planted in this man made forests. This study was amid to investigate the use Sentinel-2 satellite images for monitoring the condition of planted wood trees in Luxor Forest planation under the developed surface irrigation system and Serapium Forest planation under drip irrigation system, and estimating the efficiency of biophysical indices and NDWI derived from high resolution satellite imagery for detection spatial and temporal water stress of woody trees at planted forests in Egypt. Biophysical indices including leaf area index (LAI), canopy chlorophyll content (CCC), canopy water content $(C W C)$, fraction of absorbed photosynthetically active radiation (FAPAR), and fraction canopy cover (FCOVER), in addition to NDWI were derived from Sentinel-2 high resolution images using SNAP software. Results indicated that LAI values for Serapium forest during the winter and summer seasons show no changes. However in Luxor forest, LAI values ranged from 0 to 1.293 in winter season and in the summer season LAI recorded higher values that ranged from 0 to 2.383. This shows that woody trees in Luxor forest planation were flourish and had higher growth rates and better condition comparing with woody trees in Serapium forest. Overall, both Serapium forest and Luxor forest had low values of canopy water content during winter and summer season, which indicates that woody trees were under water stress due to not receiving the recommended amount of irrigation water. However, using developed surface irrigation system in Luxor forest resulted in better forest condition compared with drip irrigation.
\end{abstract}

Keywords-Afforestation, Sentinel 2, Biophysical indices, NDWI, Forest planation, SNAP Software.

\section{INTRODUCTION}

Egypt offers a great opportunity for large-scale afforestation due to availability of sufficient desert lands and huge volume of sewage water. Unused or improper use of sewage water is a hazard for the environment and human health and in addition a waste of water resource and valuable nutrients. In the mid-90s, the "National Programme for the Safe Use of Treated Sewage Water for Afforestation" was launched. Within the frame of this programme, around 5,000 ha plantation forests at different locations of the country were established using basictreated sewage water for irrigating the plantations. The afforestation includes different species, i.e., Acacia (Acacia nilotica and Acacia saligna), Casuarina (Casuarina equisetifolia), Cupressus (Cupressus sempervirens), Eucalyptus (Eucalyptus camaldulensis), African Mahogany (Khaya senegalensis), Neem (Azadirachta indica), Pine (Pinus pinea), in addition to 
Jatropha (Jatropha curcas) and Jojoba (Simmondsia chinensis) as biofuel crops. Egypt offers a great opportunity for large-scale afforestation due to the availability of sufficient sewage water and huge area of unutilized desert lands. Egypt currently allocates over 6.2 billion $\mathrm{m} 3$ of sewage water annually Soulie (2013). 5.5 billion $\mathrm{m}^{3}$ of this sewage water is sufficient to afforest over 600,000 ha of desert lands and store over 25 million tons of $\mathrm{CO} 2$ annually in the new plantation forests (El Kateb and Mosandl, 2012). Large-scale afforestation may stimulate cloud formation and may result in rainfall that the country urgently needs to expand its agricultural production areas (El Kateb and Mosandl, 2012). Largescale afforestation in arid regions supports innovative solutions to actual national (Egyptian) and global challenges, such as climate change mitigation, sand dunes fixation, desertification compact, renewable energy, food security and management of resources.

Moreover, afforestation is one of the most effective tools to carbon dioxide fixation. Forest products as wood and biomass are significant sources for renewable energy. One in Egypt fully neglected effect of the afforestation is its positive impact on the cultivated agriculture lands through improving their microclimate. The shelterbelts/windbreaks have the benefits of protecting cultivated lands from damage by wind, reducing plant damage by frost, sand deposit and insects, improving the efficiency of irrigation and fertilization, conserve moisture in plants and soil and thus support achieving high yield of the protected crops. Trees shelterbelts increase field and forage crops production throughout the world (Kort, 1988).

El Kateb and Mosandl (2012) determined the yield of some tree species of the plantations forests in Egypt, which was high, and estimated that the yield achieved in Egypt is approximately attained 4.5 times earlier than in Germany. If forest plantations are well managed in Egypt, the rotation period for the production of high-quality wood can be achieved in between 7 to 25 years. However, the amazing high potential for the afforestation in Egypt is yet not used at all due to lack of experience on forest management and also lack of innovative approaches to efficient use of the available resources. Neither the high potential of forest tree-growth is recognized nor that of wastewater. Sewage water has high content of the primary plant nutrients such as nitrogen and phosphorus, which are essential for plant growth. One of other channelings were facing the establishment of forest plantation in the desert land was the type of irrigation system and monitoring trees condition and forest status as response to types of irrigation system and water stress.
Remote sensing technology provide an opportunity for monitoring forest and forest plantations biophysical attributes and changes in their condition during the year which could have valuable application in implemented sustainable natural resources management plans. Recent advances in the technology have produced innovative remote sensing sensors with increasing spatial and temporal resolution of globally available satellite images such as those provided by Sentinel-2, creating new opportunities for environmental monitoring and generating accurate datasets (Belgiu et al., 2018). The Sentinel-2 mission has been improving existing earth observation capabilities with sensors that have several advantageous spectral, spatial, and temporal characteristics, compared to current satellite systems (Liu et al., 2018).

High resolution maps to evaluate vegetation dynamics and monitor forest status can be produced using Sentinel-2 satellite imagery (Eklundh et al., 2012). Studies have suggested the use of NDVI to evaluate vegetation condition from Sentinel-2 images (Eklundh et al., 2012; Tian et al., 2016; Zhang et al., 2017); however, under desert and arid lands other vegetation indices and object based image classification and analyses would be more accurate (Mohamed et. Al., 2015; Mohamed, 2018). Biophysical indices are the most importance of vegetative indices in studying plant status, water stress, and can also contribute in growth analysis afforestation and forest plantations along time series in arid zones. Vegetation indices derived from the spectral bands of the MSI Sentinel-2 sensor provide quantitative indicators of the green biomass status in forest, also, the free Sentinel 2 satellites data showed considerable potential for studies and research related to other vegetation types productivity, management, monitoring and conservation (Darvishzadeh et al., 2019; Filho et al., 2020).

Sentinel-2 satellite provide images that can be used to distinguish different crop types, monitor plant growth, and retrieve biophysical parameters, such as data on numerous plant indices, including the leaf area index, leaf chlorophyll content, and leaf water content (Clevers and Gitelson, 2013; Schlemmer et al., 2013; Hill, 2013; Frampton et al., 2013; Verrelst et al., 2015). For example, Korhonen et al., (2017) used Sentinel-2 satellite images to estimate the boreal forest canopy cover and leaf area index; Moreover, Shoko and Mutanga, (2017) tested the ability of sentinel 2 MSI sensor in detecting and discriminating differences between $\mathrm{C} 3$ and $\mathrm{C} 4$ grass species. Also another study concluded that sub-weekly biophysical variables (LAI, FCOVER, FAPAR, CCC, and CWC) derived from medium resolution $(20 \mathrm{~m})$ of Sentinel2 imagery could be estimated with reasonable uncertainties and accuracies and can be used to asses vegetation 
condition (Djamai et al., 2019). Baloloy et al. (2018) used biophysical variables extracted from Sentinel 2 satellite images to deveopl models for estimating mangrove biomass. Satellite images were processed by SNAP and ENVI software, and the following plant indicators NDVI, SAVI, GNDVI, SRRE, and biophysical indicators including LAI and FVC were calculated, the study showed efficiency of using Sentinel 2 satellite data and biophysical indicators in building models for the estimation of mangrove biomass as well as its future prediction. Lee et al. (2020) result shows that forest vertical structure in Gong-ju, Korea can be efficiently classified by using multi-seasonal Sentinel-2 satellite images and using different vegetation and water indices including NDWI.

Biophysical indices could contribute in forest growth analysis and monitoring vegetation changes during the growing season and over years, which could have practical application in the forest management and evaluation afforestation condition. The Normalized Difference Water Index (NDWI) is known to be strongly related to the plant water content, and it therefore can be a very good proxy for plant water stress. This could minimize the gap in the need to monitor the rapid change in the forest plantation health and condition and its response to water stress, as a result of plant growth, drought and water stress, management practices, pests and disease, and other human activities (ESA, 2019). The objective of this research were to 1) to use Sentinel-2 satellite images for monitoring the condition of planted wood trees in Luxor Forest planation under the developed surface irrigation system and Serapium Forest planation under drip irrigation system, and 2) to estimate the efficiency of biophysical indices and NDWI derived from high resolution satellite imagery for detection spatial and temporal water stress of woody trees at planted forests in Egypt.

\section{MATERIALS AND METHODS}

\section{Study Area Description}

\section{Serapium Forest Plantation at Ismailia}

The Serapium forest plantation was established in the year 1998 by the Ministry of State for Environmental Affairs, in cooperation with the Ministry of Agriculture and Land Reclamation of Egypt (MALR) to implement the "National Programme for the Safe Use of Treated Sewage Water for Afforestation". It is operated by the Undersecretariat for Afforestation and Environment. Initially the main objectives of the plantation were to use treated waste water, preventing its discharge in the environment, and to combat desertification. In recent years, in addition to the above mentioned purposes, the focus has shifted also toward the possibility of producing valuable wood and generating an income from wood sales (FAO 2013). The total area dedicated for planting activities is 129 ha. Currently 10 tree species are planted at Serapium forest. Total growing stock (standing wooden biomass in trunks and branches) is $4300 \mathrm{~m} 3$ (FAO, 2013) and mean annual increment ranges between $510 \mathrm{~m} 3 / \mathrm{ha} / \mathrm{y}$ depending on the species and the irrigation. The irrigation system used in the planation is drip irrigation system. Tree species and map of Serapium Forest Plantation at Ismailia developed by FAO (2012) is presented in Figure (1).

\section{Luxor Forest Plantation at Luxor}

After treatments, wastewater is pumped to Luxor man made forest next to Luxor wastewater treatment plant through water transportation tube with length of $1.2 \mathrm{~km}$. There are two large water ponds at the end of the third afforestation site which are used for storing water which coming from the treatment wastewater plant. In case of increasing the water above the daily use by the plantation and above the storage capacity of these two ponds there is an outflow path whereas the water can be discharged to the desert lands. Luxor man made forest was established in 1997 by the Undersecretariat for Afforestation and Environment. Total area allocated for of the forest plantation in Luxor is 815 . While, the total area dedicated for irrigation and planting activities is 672 ha. The cultivated area currently is 317 ha, including 255 ha of Khaya senegalensis, 51 ha of Jatropha curcas, 6.3 ha of Dealbergia sissoo, 2.3 ha Simmondsia chinensis, and 1.5 ha of Morus spp, in addition to 1 ha allocated for the plantation nursery.

Luxor forest plantation divided to tree afforestation sites according to their location and to the year of establishment. The first site was established in 1997 and has an area of 21 ha, which is planted mostly with Khaya senegalensis, in addition to some other tree species such as Dealbergia sissoo, Jatropha curcas, and Morus spp. The second afforestation site was established in 2003 with an area of 63 ha, and planted with Jatropha curcas and Khaya senegalensis. The last site was established in 2005 with planting 100 ha of Khaya senegalensis and from the year 2007 to 2009 about 225 ha was planted with Khaya senegalensis. For this study the third afforestation site with total area of 325 ha of Khaya senegalensis is considered and the developed surface (flood) irrigation system is used in this site (Figure, 2). There is no regular pruning, thinning, final harvesting of the plantation. 


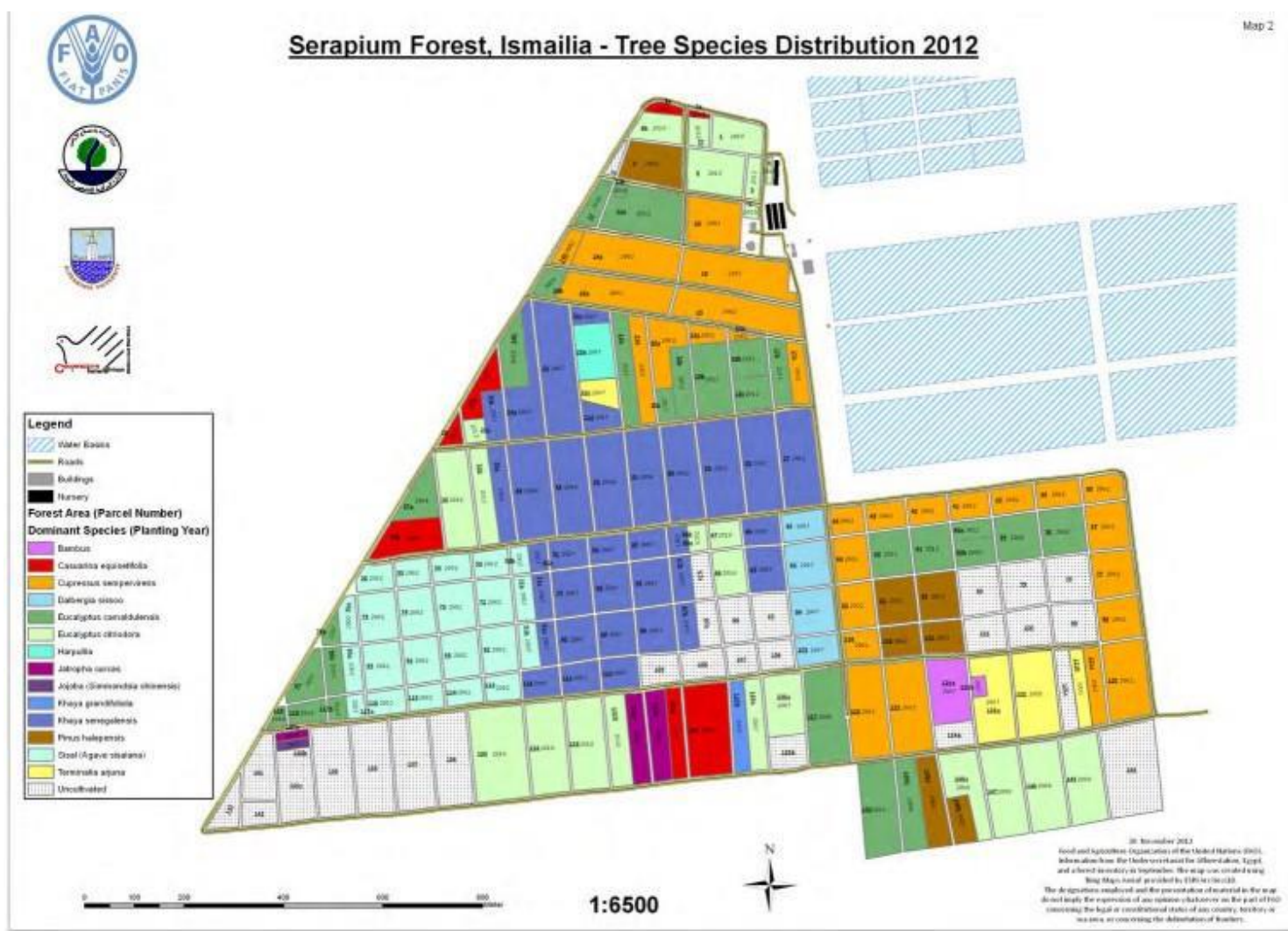

Fig.1. Tree species and map of Serapium Forest Plantation at Ismailia developed by FAO (2012).

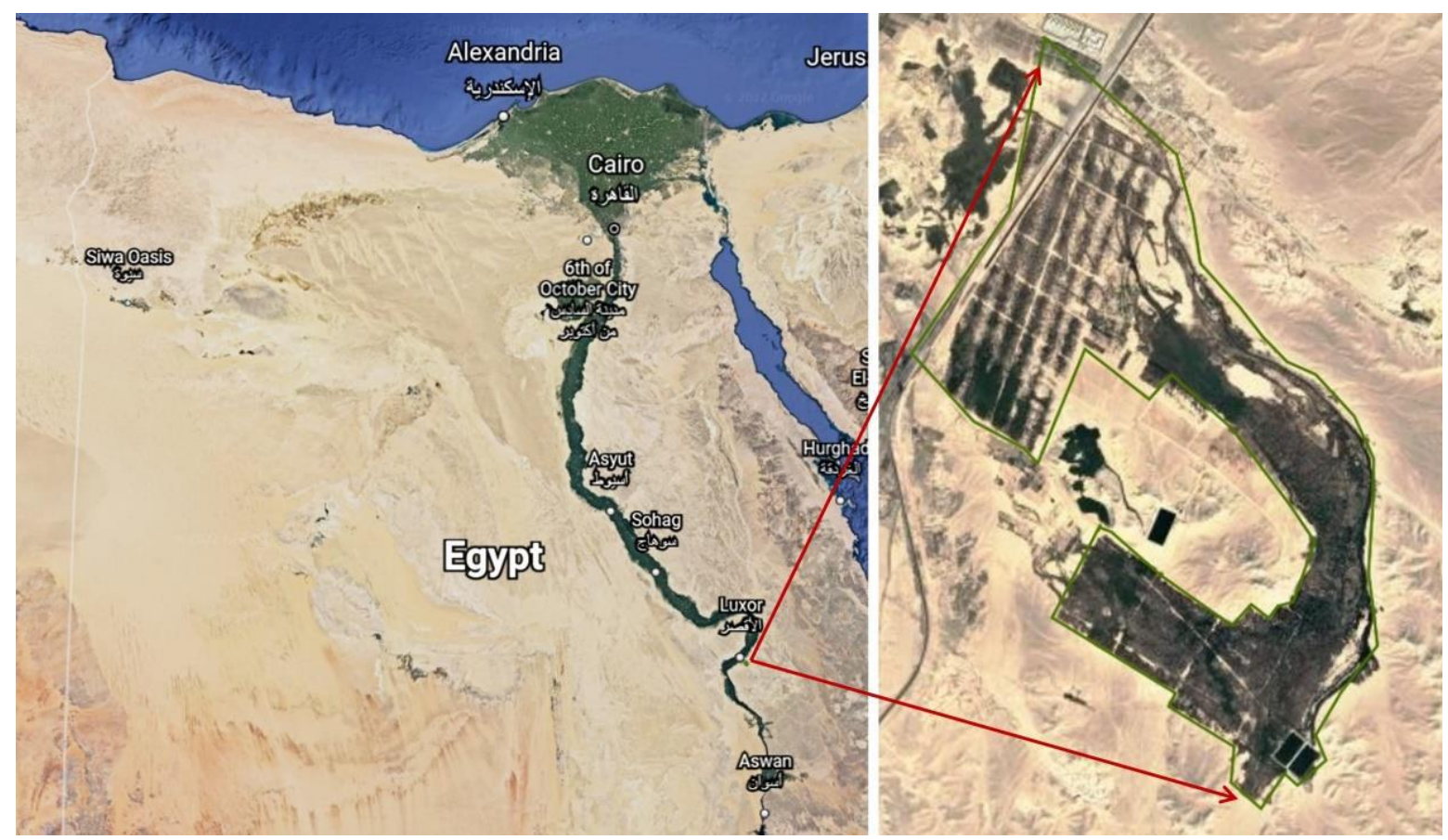

Fig.2. Luxor Forest Plantation located east Luxor, Egypt.

\section{Sentinel 2 satellite images}

Sentinel 2 satellite images were downloaded from the USGS Earth Explorer for Serapium Forest Plantation located at Ismailia and for Luxor Forest Plantation located
In Luxor in winter and summer of 2019. Details of image dates are presented in Table (1). The Copernicus Sentinel2 mission comprises a constellation of two polar-orbiting satellites placed in the same sun-synchronous orbit, phased 
at $180^{\circ}$ to each other. It aims at monitoring variability in land surface conditions and its wide swath width $(290 \mathrm{~km})$ and high revisit time (10 days at the equator with one satellite, and 5 days with 2 satellites under cloud-free conditions which results in 2-3 days at mid-latitudes) which support monitoring of Earth's surface changes. Description of Sentinel 2 satellite imagery and bands which were used in this study is shown in figure (1).

Table.1 Sentinel-2 Images date and name by Sentinel Serapium and Luxor Forest Plantations

\begin{tabular}{|l|l|l|l|}
\hline No. & Location & Date & Image code \\
\hline 1 & Serapium & $23 / 2 / 2019$ & L1C_T36RVU_A019180_20190223T083619 \\
\hline 2 & Serapium & $18 / 6 / 2019$ & L1C_T36RVU_A011916_20190618T083829 \\
\hline 3 & Luxor & $25 / 2 / 2019$ & L1C_T36RVP_A010300_20190225T083230 \\
\hline 4 & Luxor & $25 / 6 / 2019$ & L1C_T36RVP_A012016_20190625T083055 \\
\hline
\end{tabular}

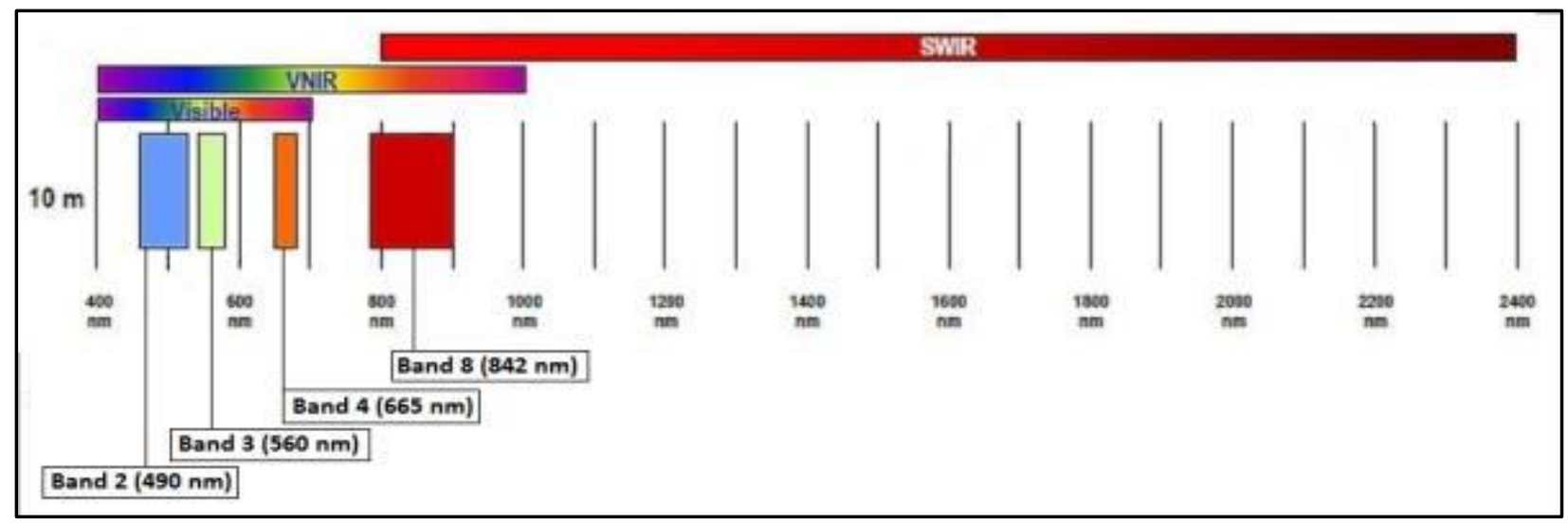

Fig.3. Sentinel-2 $10 \mathrm{~m}$ spatial resolution bands: B2 (490 nm), B3 (560 nm), B4 (665 nm) and B8 (842 $\mathrm{nm})$.

\section{Estimation of biophysical indices:}

Vegetation biophysical variables from each Sentinel-2 image were estimated using SNAP software package; these variables included LAI, FCOVER, FAPAR, CCC and CWC. LAI (Leaf area index): is a quantitative measure of the amount of live green leaf material present in the canopy per unit ground surface. It is defined as half of the total green leaf area per unit ground surface. FAPAR (Fraction of Absorbed Photo-synthetically Active Radiation): define as fraction of radiation absorbed by the photosynthesizing tissue in a canopy and estimated as a percentage, FCOVER (Fraction of vegetation cover) estimated as a percentage, CCC (Canopy Chlorophyll Content in the leaf) estimated as $\mathrm{g} / \mathrm{m} 2$, CWC (Canopy Water Content) estimated as $\mathrm{kg} / \mathrm{m} 2$. All the biophysical indices were calculated using Sentinel Natural Application Platform (SNAP) software provided without charges from ESA.

\section{Normalized Difference Water Index (NDWI):}

NDWI is an index that is widely used for vegetation analysis by using the difference of spectral characteristics according to moisture content in vegetation. The difference between NIR and SWIR, and the difference between green and SWIR, are the widely used method. In this study, values of NDWIs were generated using the difference between green (Band 3) and SWIR (Band 11) according to McFeeter (1996) and using Sentinel Natural Application Platform (SNAP) software as follows:

Band 3 - Band 11

$$
\begin{aligned}
& \text { NDWI = } \\
& \text { Band } 3 \text { + Band } 11
\end{aligned}
$$

\section{RESULTS AND DISCUSSIONS}

\section{Leaf Area Index (LAI):}

LAI estimated from the analysing of Sentential 2 satellite imagery for Serapium forest plantation and Luxor forest planation in winter and summer seasons of 2019 are presented in Figure (4) and Figure (5). LAI values for Serapium forest during the winter season ranged from 0.206 to 2.648 and no changes during the summer season was detected in LAI. For Luxor forest, LAI values ranged from 0 to 1.293, however, during the summer season LAI recorded higher values that ranged from 0 to 2.383. This can be explained as the third site of Luxor forest planation is planted by Khaya senegalensis trees, which drop some 
leaves during the winter season. It was also noted that most of Serapium forest plantation had low LAI values in compassion with Luxor forest planation as affected by the type of irrigation system, whereas developed surface irrigation system provide trees with higher amount of water in Luxor forest comparing to drip irrigation system in Serapium forest; this led to higher plant growth in Luxor forest. Also, climate conditions in Luxor are more favourable for higher trees growth comparing to Ismailia climate conditions. LAI is structural biophysical variable known as the area of one face of the plant tissue that performs photosynthesis per unit of land area, and is considered an important factor in describing many plant processes, as it determines the rates of evaporation and energy exchange from the ground vegetation cover and determines the productivity, which is an indicator of the density of vegetation cover. It is considered very important in the study of biogeochemical cycles in ecosystems (Finzel et al., 2012). To test how Sentinel-2 retrieval of LAI and Chlorophyll of tropical mixed forest canopies in India, Padalia et al., (2020) found that the corrected LAI of forest plantation stands in the study area ranged from 1.09 to 2.17 .

\section{Fraction of Absorbed Photo-synthetically Active Radiation (FAPAR):}

FAPAR estimated from the analysing of Sentential 2 satellite imagery for Serapium forest plantation and Luxor forest planation in winter and summer seasons of 2019 are presented in Figure (6) and Figure (7). FAPAR values for Serapium forest during the winter season ranged from 0.04 to 0.64 and from -0.06 to 0.72 during the summer season. For Luxor forest, FAPAR values ranged from 0 to 0.52, however, during the summer season FAPAR recorded higher values that ranged from 0 to 0.70 . This index expresses the part of the active light radiation that is absorbed by the leaf mass to carry out the process of photosynthesis, as this indicator plays an important role in the carbon cycle. Crown, this indicator is very useful as one of the inputs in productivity models (Finzel et al., 2012). It also shows that Luxor forest had better condition in comparison of Serapium forest, whereas larger areas of Luxor forest was under less water stress.

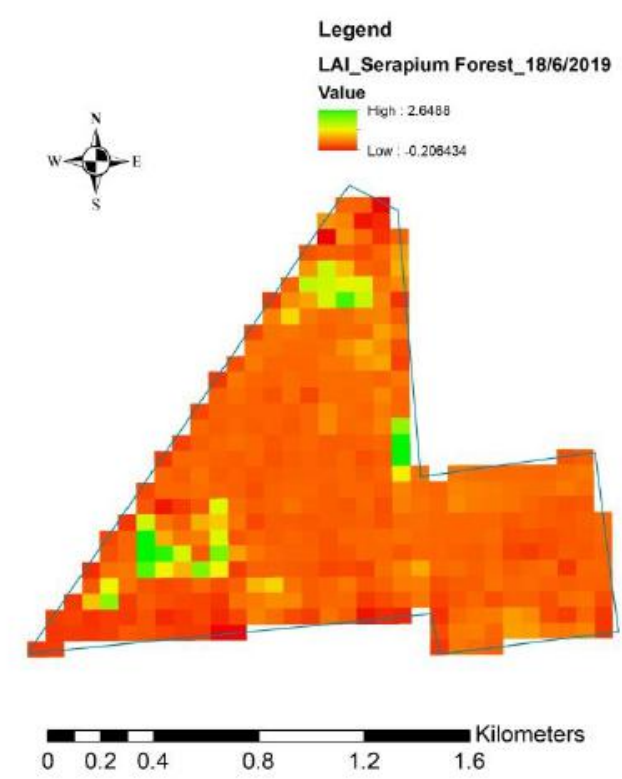

Fig.4 LAI for Serapium forest plantation during winter season at 23/2/2019 (Left) and LAI for Serapium forest plantation during summer season at 18/6/2019 (Right) 

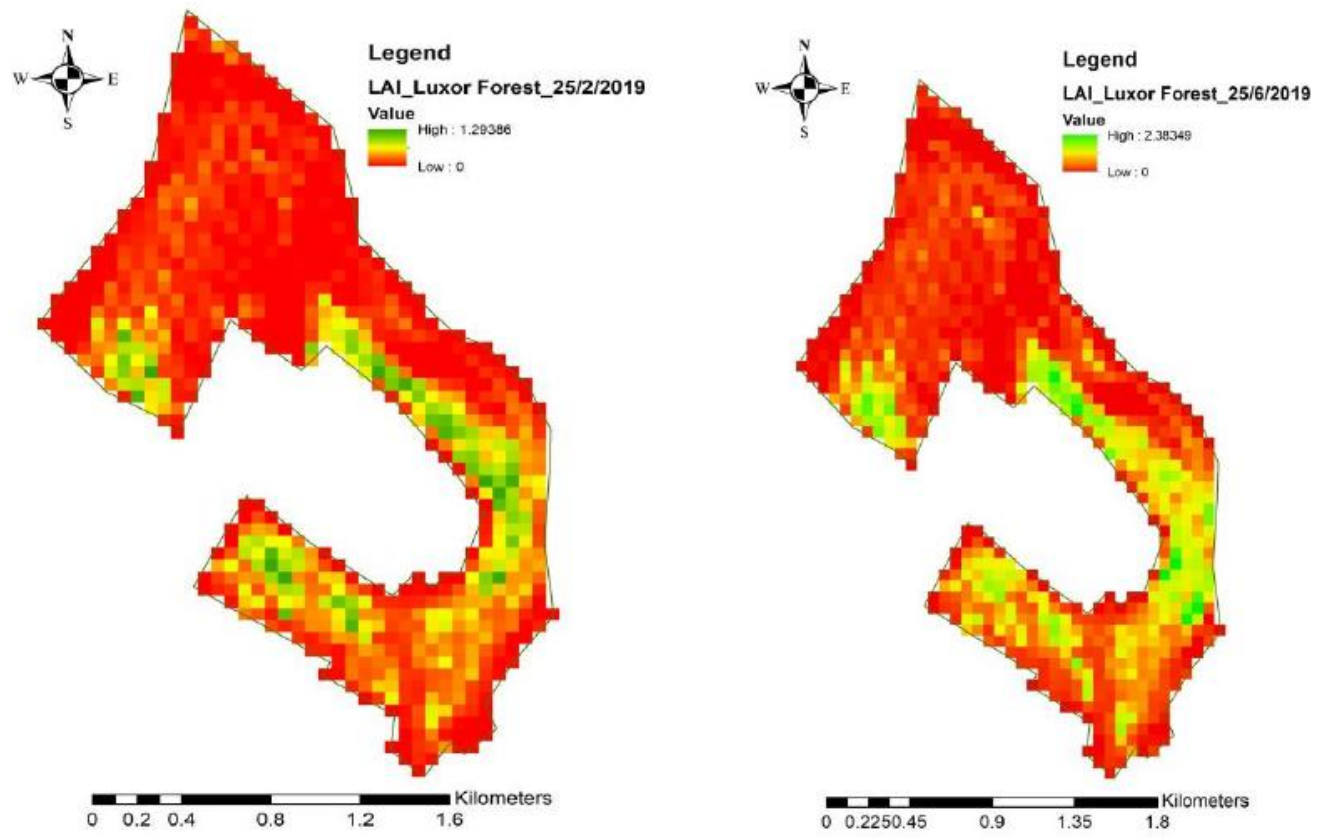

Fig.5 LAI for Luxor forest plantation during winter season at 25/2/2019 (Left) and LAI for Luxor forest plantation during summer season at 25/6/2019 (Right)
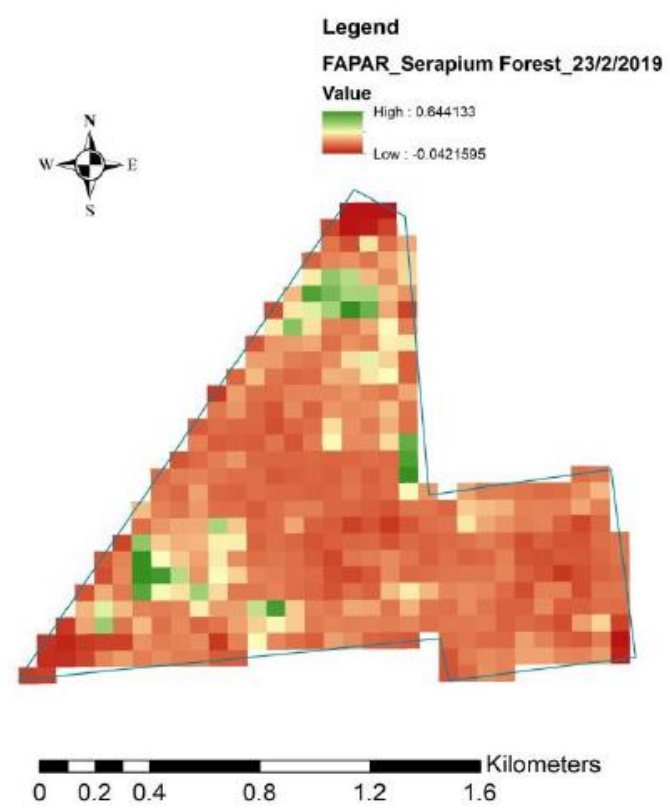

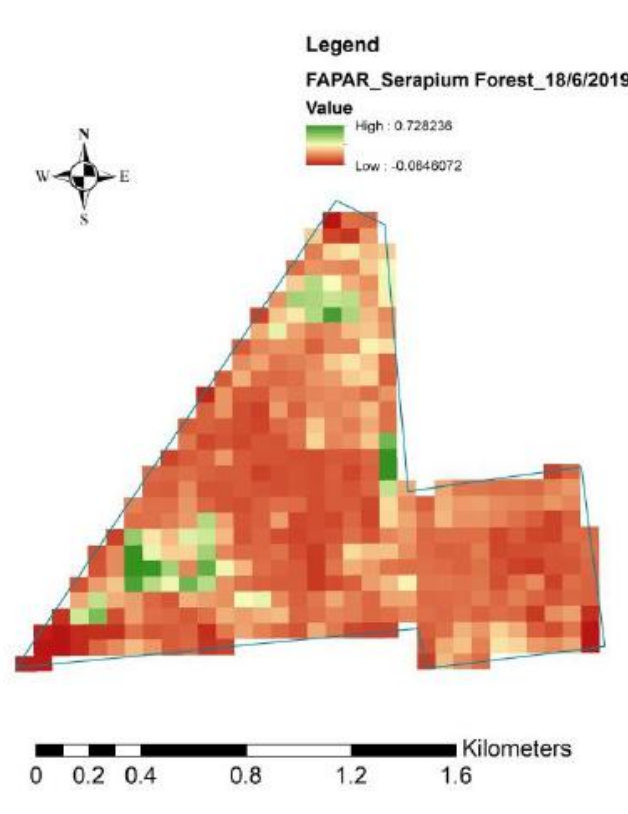

Fig.6 FAPAR for Serapium forest plantation during winter season at 23/2/2019 (Left) and LAI for Serapium forest plantation during summer season at 18/6/2019 (Right) 

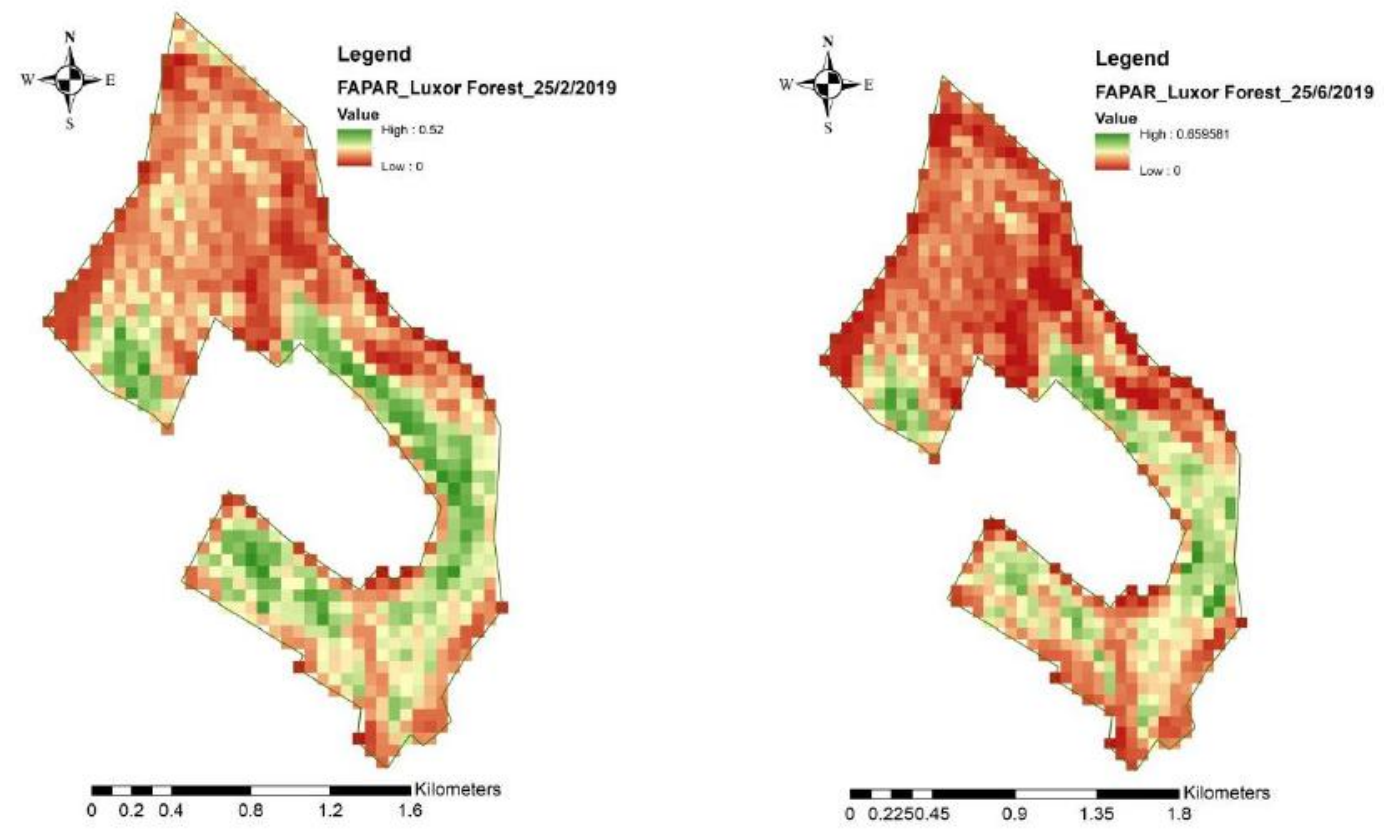

Fig.7 FAPAR for Luxor forest plantation during winter season at 25/2/2019 (Left) and FAPAR for Luxor forest plantation during summer season at 25/6/2019 (Right)

\section{Fraction of Vegetation Cover (FCOVER):}

FCOVER estimated from the analysing of Sentential 2 satellite imagery for Serapium forest plantation and Luxor forest planation in winter and summer seasons of 2019 are presented in Figure (8) and Figure (9). FCOVER values for Serapium forest during the winter season ranged from 0.02 to 0.53 and from -0.002 to 0.76 during the summer season. For Luxor forest, FCOVER values ranged from 0 to 0.50 , however, during the summer season FCOVER recorded higher values that ranged from 0 to 0.70 . Large areas the two forest plantations had low values of FCOVER that indicate both the plantations were faced frequent drought and water stress as a result of unregulated irrigation. However, Serapium forest was in poor condition as most of its area had low FCOVER values. Fractional vegetation cover is an essential parameter for characterizing the land surface vegetation conditions and plays an important role in earth surface process simulations and global change studies (Wang et al., 2018).

\section{Canopy Water Content (CWC):}

CWC estimated from the analysing of Sentential 2 satellite imagery for Serapium forest plantation and Luxor forest planation in winter and summer seasons of 2019 are presented in Figure (10) and Figure (11). CWC values for
Serapium forest during the winter season ranged from 0.028 to 0.053 and from -0.033 to 0.071 during the summer season. For Luxor forest, CWC values ranged from -.028 to 0.04, however, during the summer season CWC recorded higher values that ranged from -0.017 to 0.60. In general, both Serapium forest and Luxor forest had low values of canopy water content during winter and summer season, which indicates that woody trees were under water stress due to not receiving the recommended amount of irrigation water. It can be noted that most of Serapium forest plantation were under water stress during winter and summer seasons, however, about half of Luxor forest plantation had higher values of $\mathrm{CWC}$, which indicates that trees were in better health condition comparing with the health status of woody trees at Serapium forest. Using hyperspectral data were to assess the response of deciduous forest species dominated by European beech, Sessile and Pedunculate oak to water stress during a summery dry spell, results indicated that Moisture Stress Index (MSI), Normalized Difference Water Index (NDWI), and Chlorophyll Index (CI), revealed statistically significant differences in total chlorophyll and water concentration at the canopy level (Dotzler et al., 2015). 

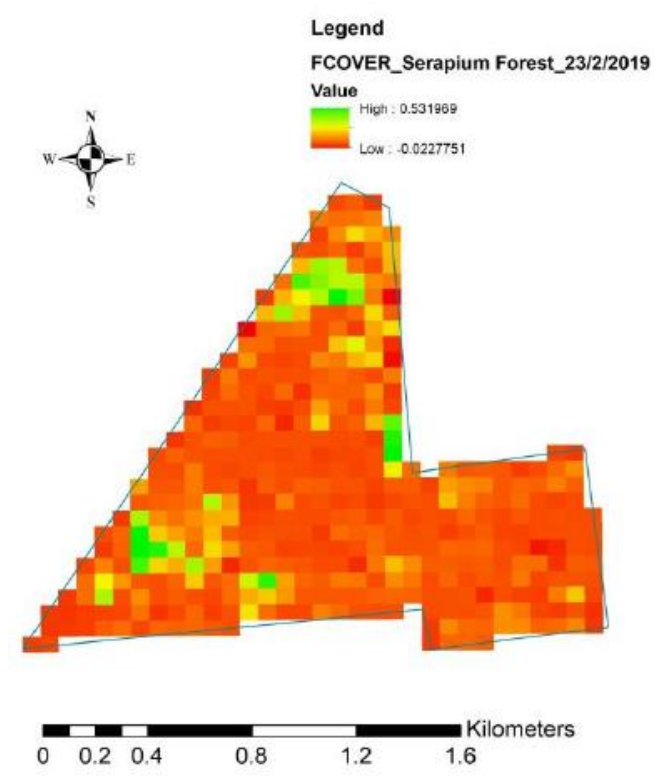

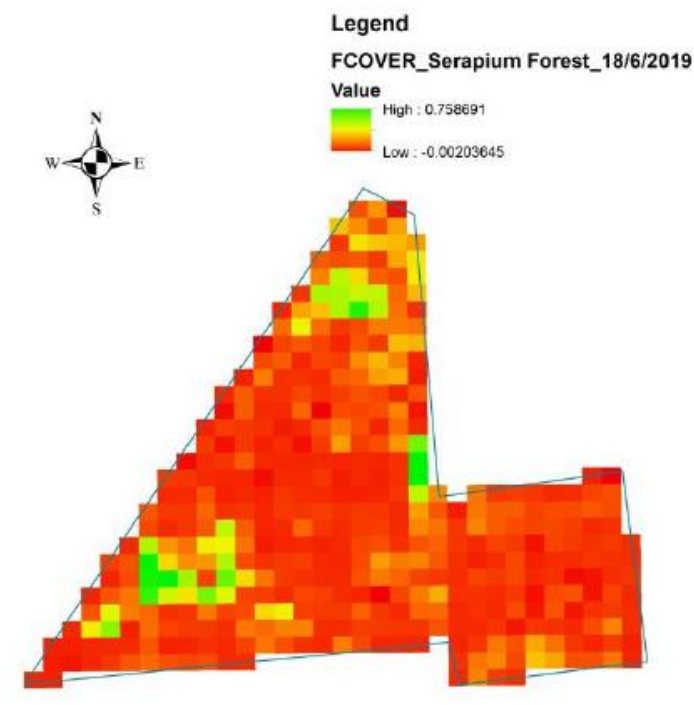

$\begin{array}{llllll}0 & 0.2 & 0.4 & 0.8 & 1.2 & 1.6\end{array}$

Fig.8 FCOVER for Serapium forest plantation during winter season at 23/2/2019 (Left) and LAI for Serapium forest plantation during summer season at 18/6/2019 (Right)
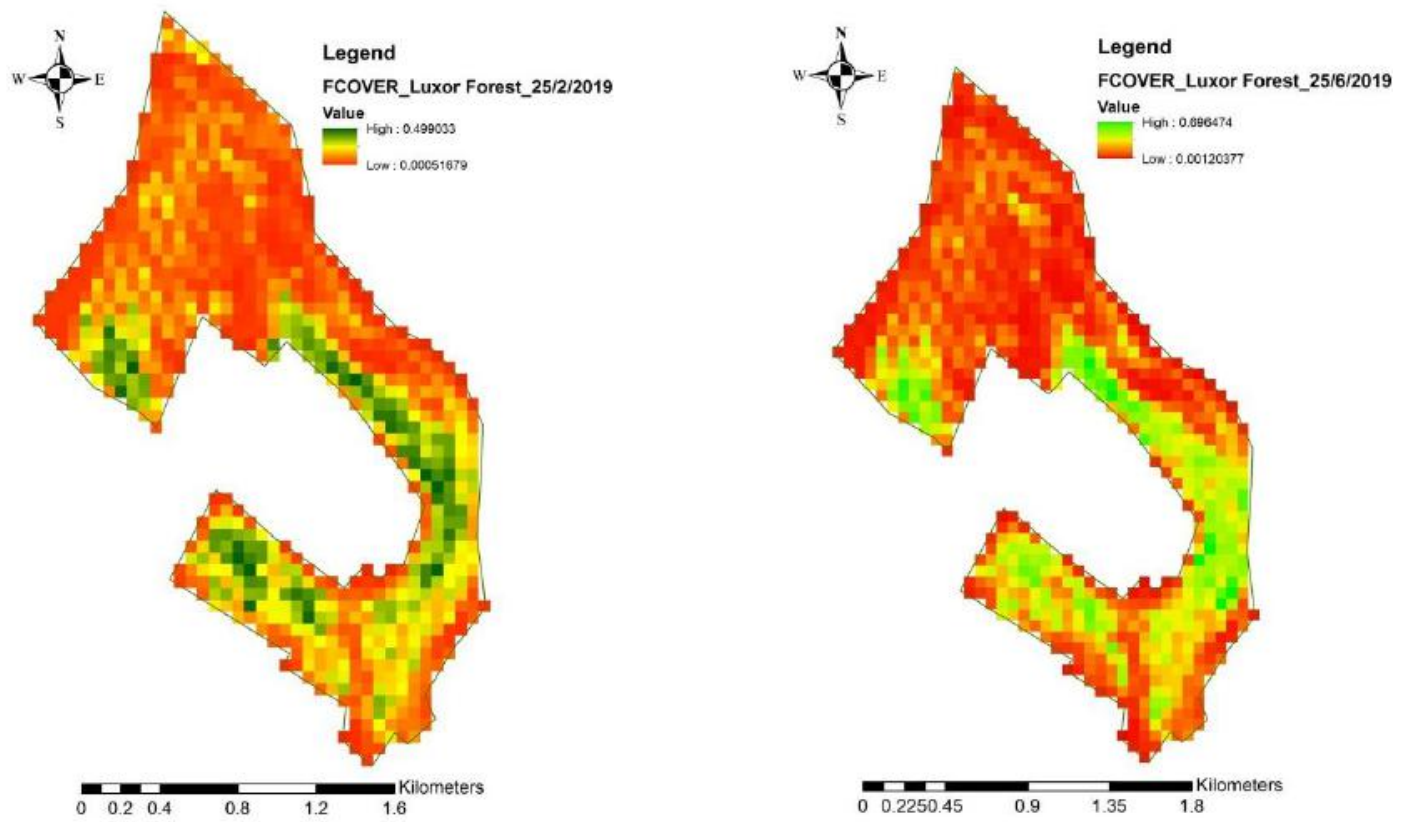

Fig.9 FCOVER for Luxor forest plantation during winter season at 25/2/2019 (Left) and FCOVER for Luxor forest plantation during summer season at 25/6/2019 (Right) 

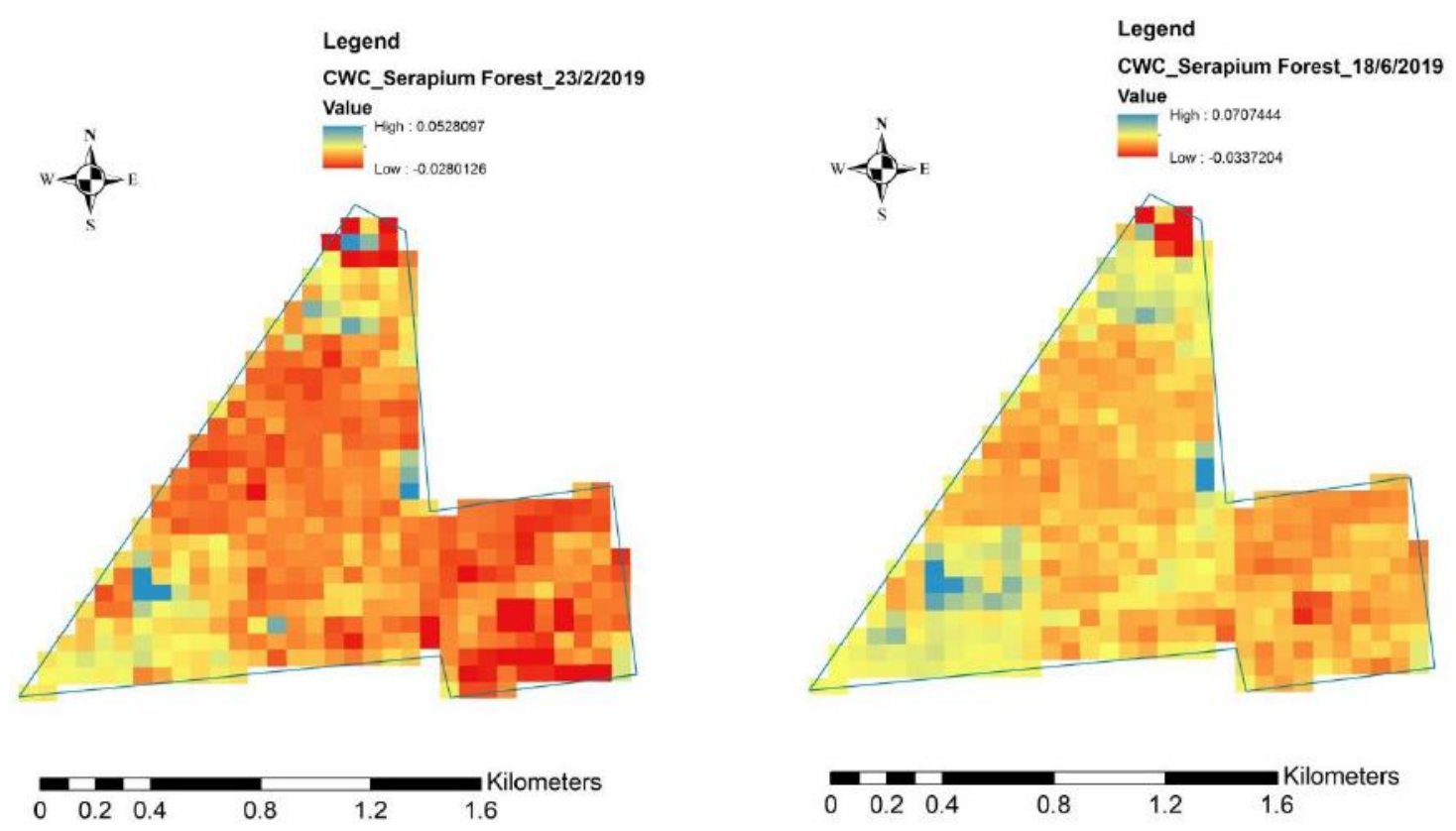

Fig.10 CWC for Serapium forest plantation during winter season at 23/2/2019 (Left) and LAI for Serapium forest plantation during summer season at 18/6/2019 (Right)
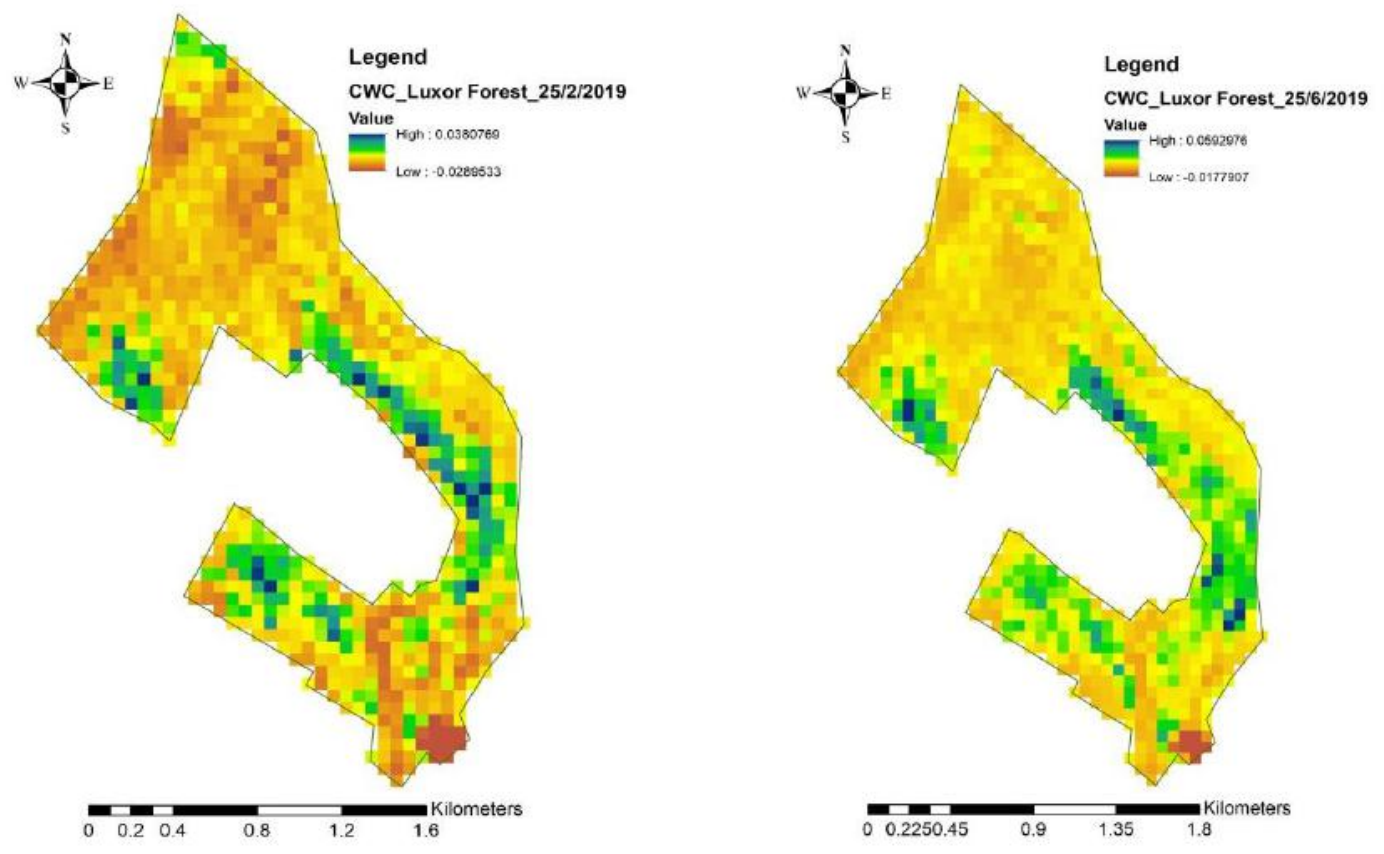

Fig.11 CWC for Luxor forest plantation during winter season at 25/2/2019 (Left) and CWC for Luxor forest plantation during summer season at 25/6/2019 (Right)

\section{Canopy Chlorophyll Content (CCC):}

CCC estimated from the analysing of Sentential 2 satellite imagery for Serapium forest plantation and Luxor forest planation in winter and summer seasons of 2019 are presented in Figure (12) and Figure (13). CCC values for
Serapium forest during the winter season ranged from 9.54 to 69.07 and from -7.56 to 98.92 during the summer season. For Luxor forest, CCC values ranged from 0 to 44.42, however, during the summer season CCC recorded higher values that ranged from 0 to 92.67 . It was noted that 
during winter seasons the CCC index recorded lower values as response to leaves drops of forest trees. Chlorophyll content is considered one of the most important indicators that can describe the state of stress that plants are exposed to, which is caused by a lack of the element nitrogen, as it is strongly related to the content of the leaves of this element (Brown et al., 2019).

\section{Normalized Difference Water Index (NDWI):}

NDWI estimated from the analysing of Sentential 2 satellite imagery for Serapium forest plantation and Luxor forest planation in winter and summer seasons of 2019 are presented in Figure (14) and Figure (15). NDWI values for Serapium forest during the winter season ranged from 0.35 to 0.62 and from -0.32 to 0.63 during the summer season. For Luxor forest, NDWI values ranged from -0.13 to 0.57 , however, during the summer season NDWI recorded higher values that ranged from -0.12 to 0.59 . Overall, Luxor forest planation had large areas with high NDWI values and the trees were under lower drought

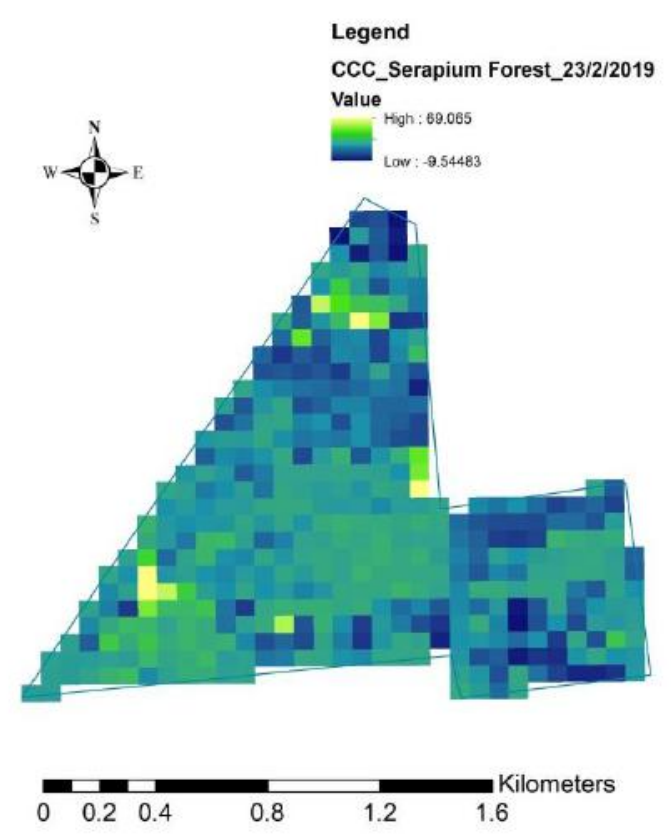

stress as the developed irrigation system was responsible for providing trees with enough irrigation water particularly during summer season. In contrast, large areas of Serapium forest planation were impacted by water and drought stress and had low NDWI values. This could be explained by the drip irrigation system that is being used in Serapium forest and the associated irrigation problems with the pumps and irrigation system, which limit the amount of irrigation water for trees. There is also the filtration system those filters help to reduce the sedimentation in irrigation water and decrease the drip irrigation break down periods, however they need to be maintained regularly in order to have high efficient irrigation system. Neri et al., (2021) showed that the integration of Sentinel-1 SAR and Sentinel-2 multispectral imagery is a promising approach in the comprehensive assessment of pine forest condition towards the early detection and monitoring of stress using NDWI and other related indices.

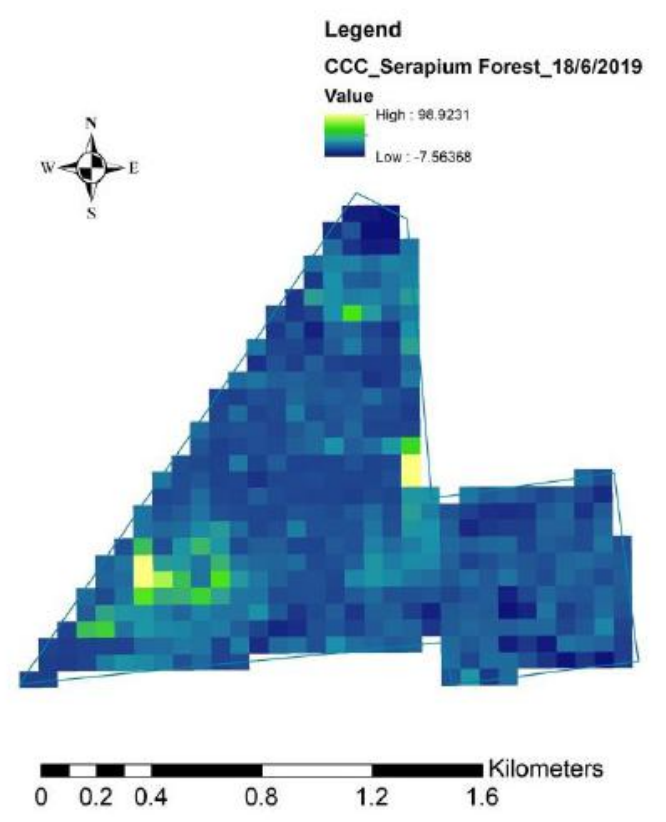

Fig.12 CCC for Serapium forest plantation during winter season at 23/2/2019 (Left) and LAI for Serapium forest plantation during summer season at 18/6/2019 (Right 

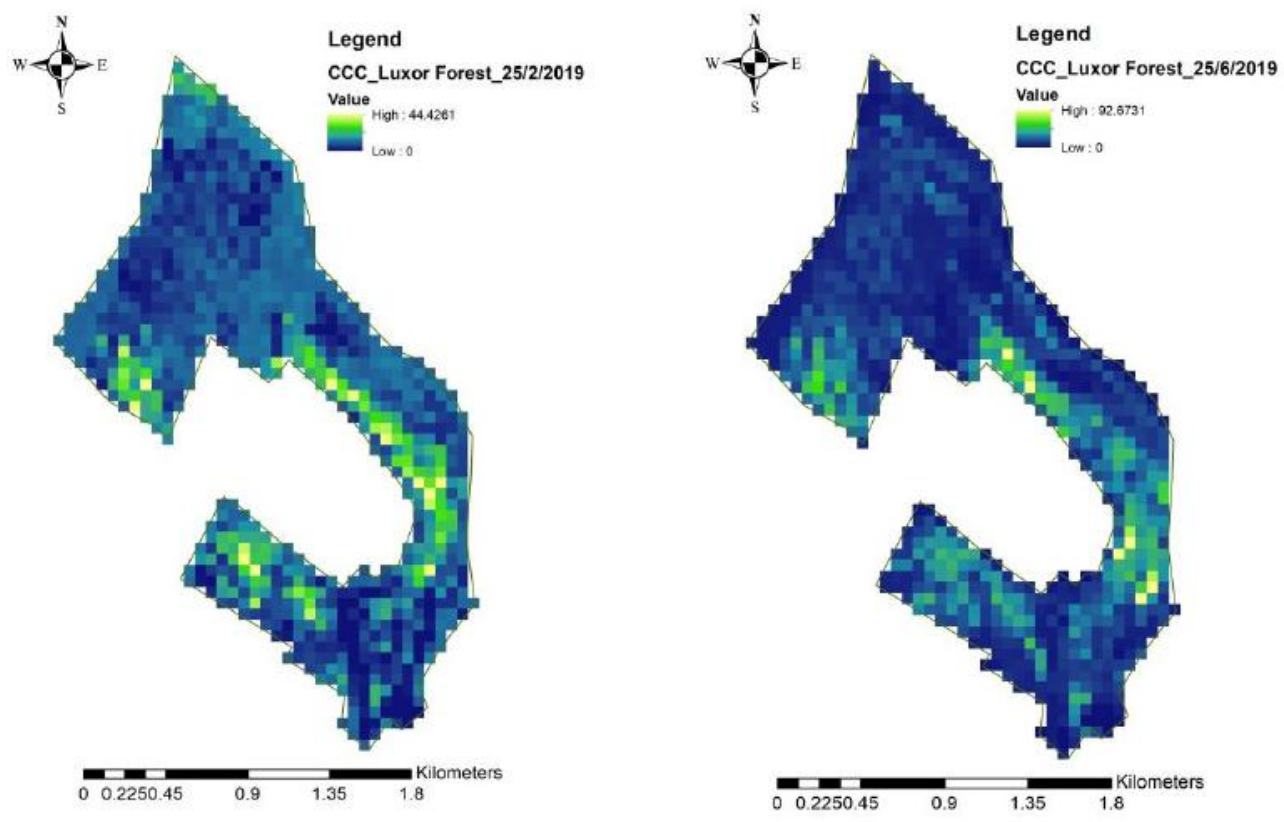

Fig.13 CCC for Luxor forest plantation during winter season at 25/2/2019 (Left) and CCC for Luxor forest plantation during summer season at 25/6/2019 (Right)
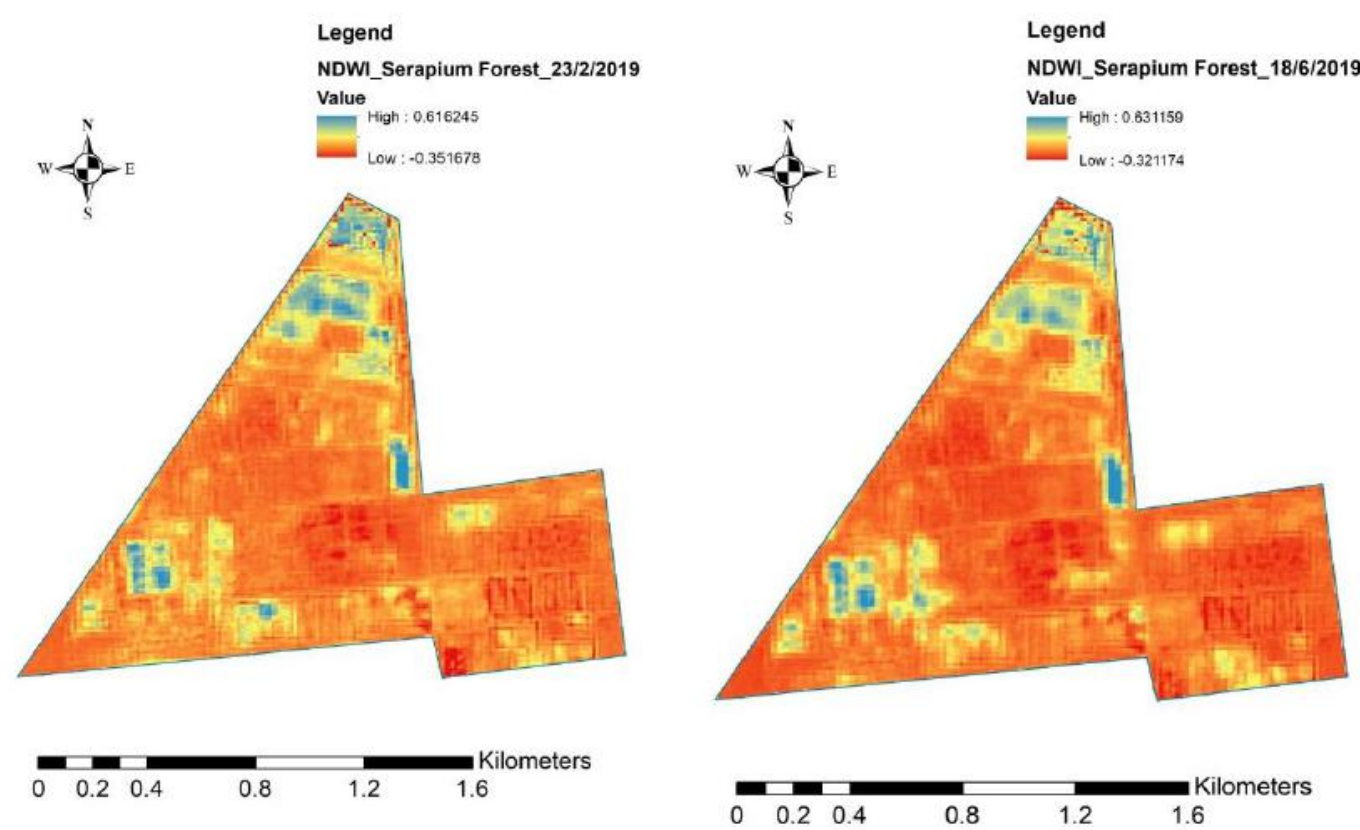

Fig.14 NDWI for Serapium forest plantation during winter season at 23/2/2019 (Left) and LAI for Serapium forest plantation during summer season at 18/6/2019 (Right 

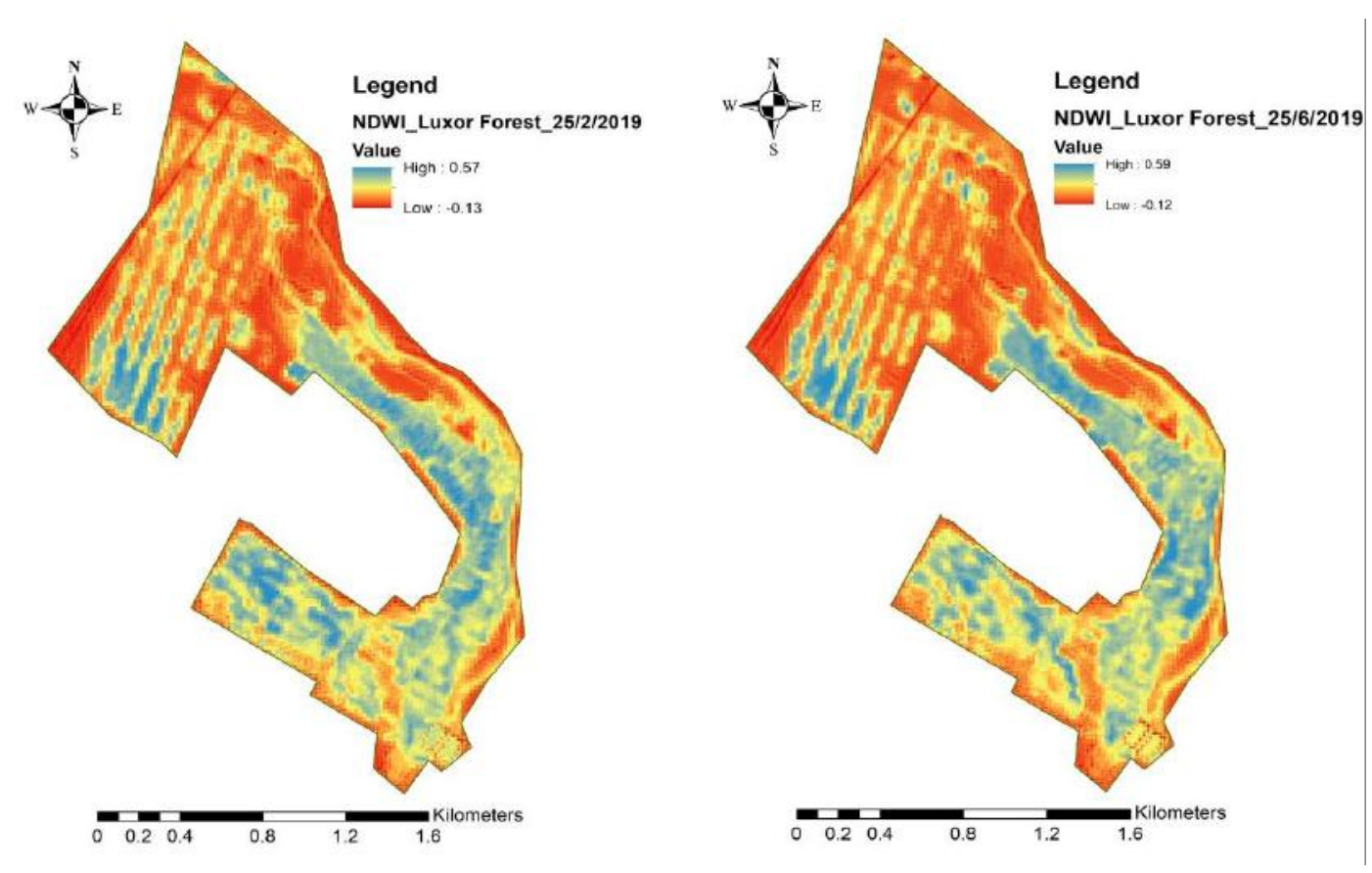

Fig.15 NDWI for Luxor forest plantation during winter season at 25/2/2019 (Left) and NDWI for Luxor forest plantation during summer season at 25/6/2019 (Right)

\section{CONCLUSION}

Given the importance of establishment of sustainable forest ecosystems in desert lands using treated waste water, the availability of reliable, spatially explicit information about the site-specific climate sensitivity of tree species to water quantities and irrigation system is essential for implementing suitable forest management plan. Luxor forest planation had large areas with high NDWI values and the trees were under lower drought stress as the developed irrigation system was responsible for providing trees with enough irrigation water particularly during summer season. It can be concluded that using Sentinel-2 satellite imager combined with biophysical and water indices showed promising capabilities of assessment of planted forest status and condition and evaluated the response of woody trees to different irrigation systems.

\section{REFERENCES}

[1] Baloloy, A.B.; Blanco, A.C.; Candido, C.G.; Argamosa, R.J.L.; Dumalag, J.B.L.C.; Dimapilis, L.L.C.; Paringit, E.C. Estimation of mangrove forest aboveground biomass using multispectral bands, vegetation indices and biophysical variables derived from optical satellite imageries: Rapideye, planetscope and sentinel-2. ISPRS Ann. Photogramm. Remote Sens. Spat. Inf. Sci. 2018, IV-3, 29-36.

[2] Belgiu, M., O. Csillik. 2018. Sentinel-2 cropland mapping using pixel-based and object-based time-weighted dynamic time warping analysis. Remote Sens. Environ. 204, 509523.
[3] Brown, L.A.; Ogutu, B.O.; Dash, J. 2019. Estimating forest leaf area index and canopy chlorophyll content with Sentinel-2: An evaluation of two hybrid retrieval algorithms. Remote Sens., 11, 1752

[4] Clevers, J.G.P.W., A.A. Gitelson .2013. Remote estimation of crop and grass chlorophyll and nitrogen content using red-edge bands on Sentinel-2 and -3. Int. J. Appl. Earth Obs. Geoinf. 23, 344-351.

[5] Darvishzadeh R., T. Wang, A. Skidmore, A. Vrieling, B. O'Connor, T. Gara, B. J. Ens, and M. Paganini. 2019. Analysis of Sentinel-2 and RapidEye for Retrieval of Leaf Area Index in a Saltmarsh Using a Radiative Transfer Model. Remote Sens., 11, 671.

[6] Djamai N., D. Zhong, R. Fernandes, and F. Zhou. 2019. Evaluation of Vegetation Biophysical Variables Time Series Derived from Synthetic Sentinel-2 Images. Remote Sens. 11(13), 1547.

[7] Dotzler, S.; Hill, J.; Buddenbaum, H.; Stoffels, J. 2015. The Potential of EnMAP and Sentinel-2 Data for Detecting Drought Stress Phenomena in Deciduous Forest Communities. Remote Sens. 7, 14227-14258.

[8] Eklundh, L., J. Ardö, P. Jönsson, and M. Sjöström. 2012. High resolution mapping of vegetation dynamics from Sentinel-2," Malmö University.

[9] El Kateb H. and Mosandl R. (2012): Aufforstungen in ägyptischen Wüstengebieten. AFZ-Der Wald 67(19): 36-39.

[10] ESA. 2019. EO4SD-Earth Observation for Sustainable Development. Agriculture and Rural Development/Service Portfolio. Available online: https://www.eo4idi.eu/sites/default/files/eo4sd_agri_portfoli o_170529_singlepag.pdf.

[11] FAO. 2013. Serapium Forest Plantation, Ismailia, Egypt: Forest Management Plan 2013-2022. 
[12] Filho M. G., T. M. Kuplich, and F. L. F. De Quadros. 2020. Estimating natural grassland biomass by vegetation indices using Sentinel 2 remote sensing data, International Journal of Remote Sensing, 41:8, 2861-2876.

[13] Finzel, J.A., Seyfried, M.S., Weltz, M.A., Kiniry, J.R., Johnson, M.V, Launchbaugh, K.L., 2012. 425 Indirect measurement of leaf area index in sagebrush-steppe rangelands. Rangel. Ecol. 426 Manag. 65, 208-212. doi:10.2111/REM-D-11-00069.1

[14] Frampton, W.J., Dash, J., Watmough, G., Milton, E.J., 2013. Evaluating the capabilities of Sentinel-2 for quantitative estimation of biophysical variables in vegetation. ISPRSJ. Photogramm. Remote Sens. 82, 83-92.

[15] Hill, M.J., 2013. Vegetation index suites as indicators of vegetation state in grassland and savanna: an analysis with simulated Sentinel-2 data for a north American transect. Remote Sens. Environ. 137, 94-111.

[16] Korhonen, L., Hadi, Packalen, P., Rautiainen, M., 2017. Comparison of Sentinel-2 and Landsat 8 in the estimation of boreal forest canopy cover and leaf area index. Remote Sens. Environ. 195, 259-274.

[17] Kort, J. (1988) Benefits of windbreaks to field and forage crops. Agriculture, Ecosystems and Environment, 22/23: 165-190.

[18] Lee, Y.S.; Lee, S.; Jung, H.S. 2020. Mapping forest vertical structure in Gong-Ju, Korea using sentinel-2 satellite images and artificial neural networks. Appl. Sci., 10, 1666.

[19] Liu, T.; Liu, X.; Liu, M.; Wu, L. 2018. Evaluating Heavy Metal Stress Levels in Rice Based on Remote Sensing Phenology. Sensors, 18: 860.

[20] Mohamed A. H. 2018. Using high spatial resolution satellite imagery to evaluate the impact of mesquite invasion on desert rangeland at southeastern Egypt. J. Bio. Env. Sci. 13(3), 167-176.

[21] Mohamed A. H., El Shesheny M.A. , Hendawy S.H., Mahmoud H. S.(2015). Assessing Mesquite Cover Change in Southeastern Egypt using High Resolution Satellite Images. Current Science International 4(3): 351-357.

[22] Neri, M.E.P, Recto, B.A.B, Blanco, A.C., Ramos, R.V. 2021. Assessment of Pine Forest Condition Towards Early Detection and Monitoring of Stress Through a Synergistic Use of Sentinel-1 and Sentinel 2 Imagery. Journal of Advanced Geospatial and Science Technology. 1(1), 1-18.

[23] Padalia H, Sinha SK, Bhave V, Trivedi NK, Kumar AS. 2020. Estimating canopy LAI and chlorophyll of tropical forest plantation (North India) using Sentinel-2 data. Adv Space Res. 65(1):458-469.

[24] Schlemmer, M., Gitelson, A., Schepers, J., Ferguson, R., Peng, Y., Shanahan, J., Rundquist, D. 2013. Remote estimation of nitrogen and chlorophyll contents in maize at leaf and canopy levels. Int. J. Appl. Earth Obs. Geoinf. 25, 47-54.

[25] Shoko, C., Mutanga, O., 2017. Examining the strength of the newly-launched sentinel 2 MSI sensor in detecting and discriminating subtle differences between $\mathrm{C} 3$ and $\mathrm{C} 4$ grass species. ISPRS-J. Photogramm. Remote Sens. 129, 32-40.

[26] Soulie, M. (2013) Review and analysis of status of implementation of wastewater strategies and/or action plans;
National Report Egypt. Sustainable Water Integrated Management: $\quad$ http://www.swimsm.eu/files/National_Report_WW_strategies-EG_Final.pdf.

[27] Tian, F.; Brandt, M.; Liu, Y.Y.; Verger, A.; Tagesson, T.; Diouf, A.A.; Rasmussen, K.; Mbow, C.; Wang, Y.; Fensholt, R. 2016. Remote sensing of vegetation dynamics in drylands: Evaluating vegetation optical depth (VOD) using AVHRR NDVI and in situ green biomass data over West African Sahel. Remote Sens., 177, 265-276.

[28] Verrelst, J., Rivera, J.P., Veroustraete, F., Muñoz-Marí, J., Clevers, J.G.P.W., Camps-Valls, G., Moreno, J., 2015. Experimental Sentinel-2 LAI estimation using parametric, nonparametric and physical retrieval methods- a comparison. ISPRS-J. Photogramm. Remote Sens. 108, 260-272.

[29] Wang, B.; Jia, K.; Liang, S.; Xie, X.; Wei, X.; Zhao, X.; Yao, Y.; Zhang, X. 2018. Assessment of Sentinel-2 MSI Spectral Band Reflectances for Estimating Fractional Vegetation Cover. Remote Sens. 10, 1927.

[30] Zhang, T.; Su, J.; Liu, C.; Chen, W.-H.; Liu, H.; Liu, G. 2017. Band Selection in Sentinel-2 Satellite for Agriculture Applications. In Proceedings of the 2017 23rd International Conference on Automation \& Computing, Huddersfield, UK, 7-8 September. 